Steffen Fleßa

\title{
Innovations in healthcare of peripheral regions - Greifswald as incubator for the Baltic Sea region?
}

\begin{abstract}
Health care systems are called to reconcile at least three conflicting goals: They have to provide sufficient health care services of appropriate quality for the population, keep the cost at an affordable level, and make services accessible for every member of the society. Achieving all three of these goals at the same time is sometime like squaring the circle: Good services accessibly for everybody even in peripheral regions require resources and generate costs which - too often - seem inappropriate for many politicians and members of the society. At the same time, high quality services are only affordable with centralised systems where the number of patients permits sufficient routine. However, this centralisation means that services are not available close of the places where people live, in particular in rural areas. The only answer are innovations of health care provision which increase the efficiency of the system and make it possible to achieve all objectives at the same time.

The district of Vorpommern-Greifswald has developed, adopted, and implemented innovations in the field of telemedicine, emergency services, drones, and cross-border health care, which have already proven relevant for the region. These innovations are ready to diffuse into other countries of the Baltic Sea region. At the same time, innovations from other countries could be fruitful innovations seedlings for the district in North-Eastern Germany. However, this would require overcoming a number of financial, cultural, and personal barriers in order to improve the health care situation even in peripheral regions.
\end{abstract}


This paper discusses the "magic triangle" of cost, quality, and accessibility as the fundamental goal system of a health care system. Furthermore, it presents some insights into the innovations implemented in the district of Vorpommern-Greifswald. Finally, it discusses a model of innovation adoption and potentials entering into an adoption and adaption process within the Baltic Sea region.

Keywords: cross-border health care, drone, innovation, innovation model, telemedicine, telemedicine emergency doctor services.

\section{Dilemma of rural healthcare in peripheral regions}

The Covid-19 pandemic demonstrated that it has advantages to be peripheral. EU-countries in the North were quite far away from the epicentre of the early epidemic in Europe and this distance gave these countries sufficient time to prepare themselves. Consequently, the first wave of Covid-19 almost spared Norway, Finland and the Baltic countries. Even within countries, remote and peripheral districts were reached much later and were not hit so fiercely as the centres. It seems that it can be a blessing to live in a peripheral region.

However, peripheral location is usually seen as a disadvantage, in particular for healthcare. The most important handicaps associated with the periphery are ${ }^{1}$ :

Economic strength and potential: Peripheral regions frequently have a lower economic productivity, poor infrastructure and low intellectual capital in comparison to centres, i.e., the education level, the innovativeness, the gross national product per capita, the quality of roads and the likelihood of founding new enterprises are lower. Consequently, the prospects of changing these economic outcomes are rather poor.

Demography: Due to the poor economic situation, many young people in the fertile age leave peripheral regions to work and live in the centres. The elderly remain in their villages and the average age is high. Logical consequences are a low reproductive rate (as the elderly do not have children any more), high morbidity and mortality.

1 J. Bernard et al., "Living and dealing with limited opportunities: social disadvantage and coping strategies in rural peripheries," Sociální studia/Social Studies 13, no. 2 (2016): 29-53. 
Low mobility: Poor infrastructure and economic potential as well as a high average age have an impact on the spatial mobility of the population in the periphery. Providing public transport is much more expensive per capita than in highly populated centres, resulting in the dependence on private cars. With increasing age, the ability to drive becomes a challenge.

The term "periphery" describes the outer limits or edge of an area. ${ }^{2}$ Like in a circle, where we can distinguish a centre and a perimeter, any geographical unit can have a centre and a periphery while the centre does not have to be in the middle of the geographical unit. The variable defining periphery cannot be Euclidean distance, but it is mainly temporal, emotional and cultural distance, i.e., a peripheral place is difficult to reach because it takes a long time to approach it or because a psychological barrier has to be overcome to access it. Depending on the geographical unit, a place might be seen as centre and periphery at the same time. For instance, Helsinki is the centre of Finland but it might be perceived as the periphery of EU-Europe. Consequently, there is no ultimate criteria to define which region is peripheral. For this paper we will use the term in a broad sense, i.e., a peripheral region is further away from the centre and has the characteristics described above (e.g. poor economic strength and potential, high average age, poor mobility).

These negative associations are of high importance for the provision of healthcare services in the periphery ${ }^{3}$ :

Low population density: A low population density does not allow the establishment of big healthcare institutions. Hospitals, for instance, will have a lower bed capacity. This leads to higher costs per service unit (e.g. bedday or case), but also to lower quality as the quality of healthcare services increases with experience and volume.

Morbidity: The quantity and quality required for healthcare services increases with age. With the exemption of neonates, children and younger adults do not require the frequency and intensiveness of hospital and ambulatory care. However, the prevalence of chronic-degenerative diseases strongly increases with age leading to a higher demand for services while the treatment of multi-morbid elderly becomes much more difficult and resource-intensive.

2 S. P. Borgatti and M. G. Everett, "Models of core/periphery structures," Social networks 21, no. 4 (2000): 375-395.

3 S. Fleßa, Kleinere Krankenhäuser im ländlichen Raum (Berlin, Heidelberg: Springer, 2020). 
Distance: Accessibility of healthcare services is hardly a challenge in centres with high population density and a sufficient number of healthcare providers. In the periphery with low population density, higher average age and poor mobility, distance is the most crucial factor determining accessibility.

The consequence of these factors is a comparably poor health status in peripheral regions. While the correlation between periphery and poor health is empirically correct, we would like to challenge the assumption that poor health is an inevitable consequence of periphery. Instead, we would like to show that healthcare innovations have the potential to overcome the shortcomings of peripheral regions. For this purpose, we will first analyse the goal conflict in the magic triangle of quality, cost and accessibility of healthcare services. Afterwards we will analyse some innovations of healthcare generated in the German North-Eastern district of Vorpommern-Greifswald with the potential to relax the respective disadvantages of the periphery. In another section, we will develop a model of adopting these innovations in order to determine the likelihood that they will be adopted in the Baltic Sea region. We close with a discussion of these findings and some recommendations of how to foster innovation adoption.

\section{Magic triangle}

\subsection{Overview}

Healthcare frequently follows a multi-dimensional goal system, i.e., healthcare services should achieve several objectives at the same time ${ }^{4}$ :

Quality: Healthcare services should be effective, i.e., healthcare interventions should heal diseases, increase the quality of life or - at least - alleviate suffering. For this purpose, healthcare services must have a sufficient quality.

Affordability: Healthcare services require resources. The consumption of these resources (= cost) must be affordable for the individual and the society. While most EU-countries have implemented comprehensive health insurance systems, most patients still suffer from time and transport cost of accessing the point of service.

4 S. Fleßa and W. Greiner, Ziele- und Wertesystem. Grundlagen der Gesundheitsökonomie (Heidelberg: Springer, 2020): 11-36. 
Accessibility: Healthcare services frequently require that the healthcare provider and the patient meet in unity of time, place and action, i.e., the patient must come to the provider or the provider to the patient. As services cannot be transported or stored, overcoming the barrier of distance is crucial for successful healthcare services. Private, public and in particular ambulance transport are means to increase accessibility.

Sustainability: Services should not only be provided today, but also in future. Inter-temporal allocation of funds is a difficult decision, but it is unavoidable in order to safeguard that services are sustainable.

Participation: The patient and the society are stakeholders directly affected by healthcare services. Thus, they have a right to participate in the decision-making concerning their health.

It is obvious that there are strong goal conflicts between these dimensions of the goal system. For instance, high quality of services will most likely require more resources and induce higher costs. At the same time, good accessibility will require many healthcare institutions accessible in acceptable time. This will, however, increase the costs of healthcare and challenge the quality. Consequently, cost, quality and accessibility are in conflict, and we need an instrument to overcome or relax this goal conflict.

In the following, we will analyse the situation in a rural, peripheral district of North-East German called Vorpommern-Greifswald. We will first analyse these three dimensions and then demonstrate the goal conflict for this district.

\subsection{Cost}

The cost per service unit are likely higher in peripheral regions than in centres. The low population density does not permit the establishment of big institutions. In particular, hospitals in the periphery will have fewer admissions, beddays and beds than hospitals of the same level in centres.

The lower capacity results in higher unit costs due to a number of economic principles:

Fixed cost degression: Fixed cost are cost which do not change with utilisation. Some $60-70 \%$ of total costs of hospitals are fixed, i.e., they do not alter with bed occupancy or number of cases. Whether $70 \%, 80 \%$ or $90 \%$ of beds are occupied, the administration, the x-ray department,

\footnotetext{
5 G. Wöhe, U. Döring and G. Brösel, Einführung in die allgemeine Betriebs-wirtschafts-
} lehre (München: Vahlen, 2016). 
the laboratory etc. will all require staff and induce costs. Consequently, an increasing utilization will spread the fixed costs over a bigger number of patients and lead to lower unit costs. This principle is called fixed cost degression.

It can be shown that smaller units have a higher risk of poor occupancy as they cannot compensate the ups and downs of demand so easily. ${ }^{6}$ Consequently, smaller hospitals will have a lower occupancy resulting in higher unit costs.

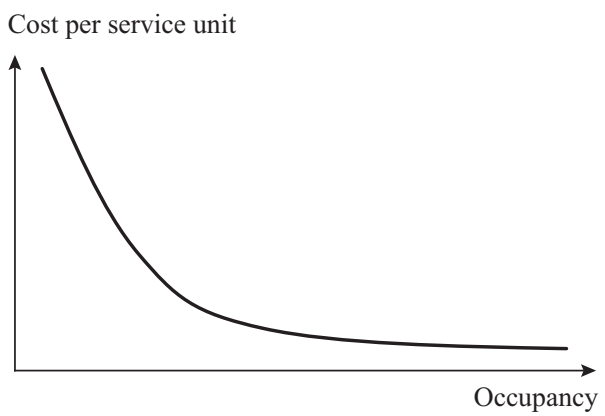

Figure 1. Fixed cost degression (Fleßa 2018)

Economies of scale: Frequently, one business units with a high capacity has lower costs per service unit than several smaller units with the same total capacity. ${ }^{7}$ For instance, the cost of one kWh of electricity of a 500-MW power station is lower than the respective cost of 10 power stations with $50 \mathrm{MW}$ each. The cost per patient of a 400-beds hospital are usually lower than the costs in 10 hospitals of 40 beds each if they want to hold the same quality. This is due to the fact that each hospital needs a certain infrastructure, such as laboratory, x-ray department, kitchen etc. A 400-beds hospital will have higher fixed costs than a 40 beds hospital, but never 10 times as high.

The consequence of economies of scale is that it is worthwhile to concentrate services in few centres instead of distributing many small hospitals throughout the countryside. There are, however, also diseconomies of scale when the units become too large.

6 S. Fleßa, "Ineffizienz ohne Verschulden. Die variationsbedingten Nachteile kleiner Abteilungen," Das Krankenhaus 99 (2007): 544-549.

7 S. Fleßa, Systemisches Krankenhausmanagement (Berlin: DeGruyter, 2018). 


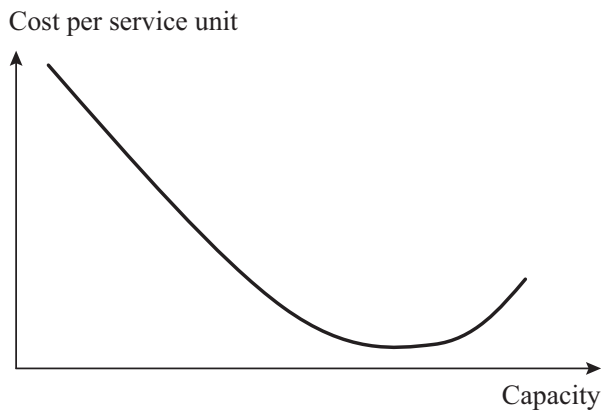

Figure 2. Economies (and diseconomies) of scale (Fleßa 2018)

Economies of scope: Business units with a broad scope of services tend to have lower cost per service unit. ${ }^{8}$ Theoretically, special services could be distributed to different hospitals, i.e., one hospital gets heart surgery, another one cardiology, one hospital runs a department of neurosurgery, another hospital a stroke unit. However, these special units use other functions of the hospital, such as imaging, laboratory etc. It is much more efficient to concentrate all specialities in one hospital with a broad scope of services so that all specialities can use the sophisticated secondary functions of the hospital. However, there are also diseconomies of scope as the complexity of business units increases exponentially with the number of departments.

Cost per service unit

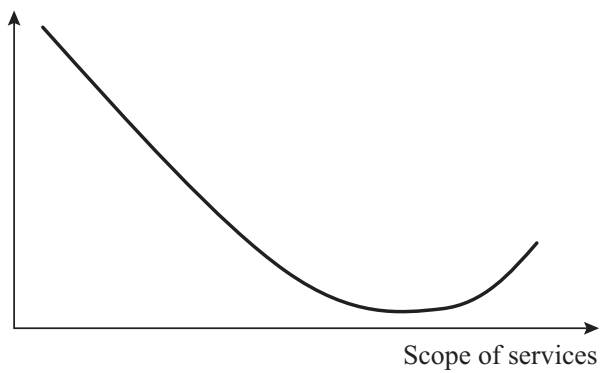

Figure 3. Economies (and diseconomies) of scope (Fleßa 2018)

8 Fleßa (2018). 
Fixed cost degression, economies of scale and economies of scope clearly indicate that larger healthcare facilities in centres with a high population density will have lower cost per service unit. This is a major economic challenge: Providing the same quality and quantity of healthcare in peripheral regions will be more expensive per inhabitant, but the income of the population is lower. Economic rationality calls for a reduction of the number of hospitals and a concentration in fewer locations so that the institutions become larger and harvest the economies mentioned above. However, this might have consequences on the quality and accessibility of services.

\subsection{Quality}

Quality of healthcare services can be partly measured by results such as mortality, infection rates or waiting times. As in many other cases, the result quality of a service will increase with the number of services rendered. For instance, if a surgeon performs a certain operation more frequently, he will not only be faster, but also better, i.e., he will make fewer mistakes and have the routine to respond to seldom events and emergencies. ${ }^{9}$ The "normal" process might be handled perfectly, but events with a lower probability will result in a major challenge for smaller service units as they occur so rarely that the respective personnel has no experience with it. For instance, a "normal" delivery can be handled by a midwife without problems even if she does only one delivery per week. However, once an emergency occurs during delivery, the last critical incident might be too long ago and she becomes overwhelmed. A larger hospital with 10 times as many deliveries is more likely to have a routine in handling even difficult situations. Consequently, most studies (but not all) indicate a significant positive relation between volume and outcome of healthcare services. ${ }^{10}$

The quality curve clearly implies that the quality of treatment in larger hospitals will increase with the number of patients, beddays and beds. This calls for concentration if we focus only on the quality within a hospital. However, the quality of the transport to the hospital is also relevant.

9 Fleßa (2018).

10 National Research Council, Interpreting the volume-outcome relationship in the context of cancer care (Washington D.C.: National Academies Press 2001); D. Pieper et al., "State of evidence on the relationship between high-volume hospitals and outcomes in surgery: a systematic review of systematic reviews," Journal of the American College of Surgeons 216, no. 5 (2013): 1015-1025. e1018. 


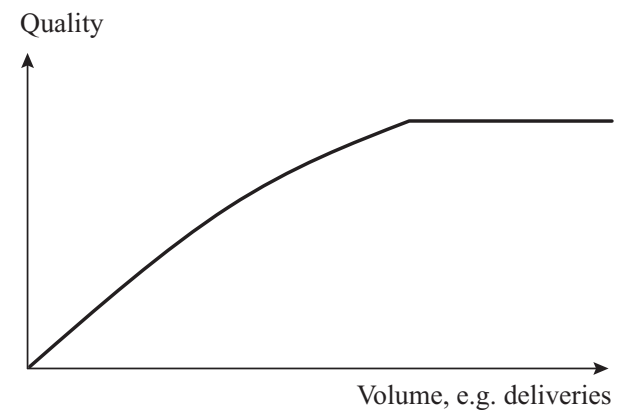

Figure 4. Quality curve (Fleßa 2018)

Figure 5 shows that the quality of transport decreases if the distance between the location of the emergency and the healthcare facility increases while the quality in the healthcare facility increases. Consequently, there is an "optimum" of the total quality, which is between the extrema. From a quality perspective, it is neither appropriate to build many small hospitals throughout the peripheral region, nor is it appropriate to concentrate all services in very few places. However, the quality curve depends on the degree of emergency. While a road accident will require rapid access to a healthcare facility, many elective procedures will not be affected even if the distance to the hospital is rather high.

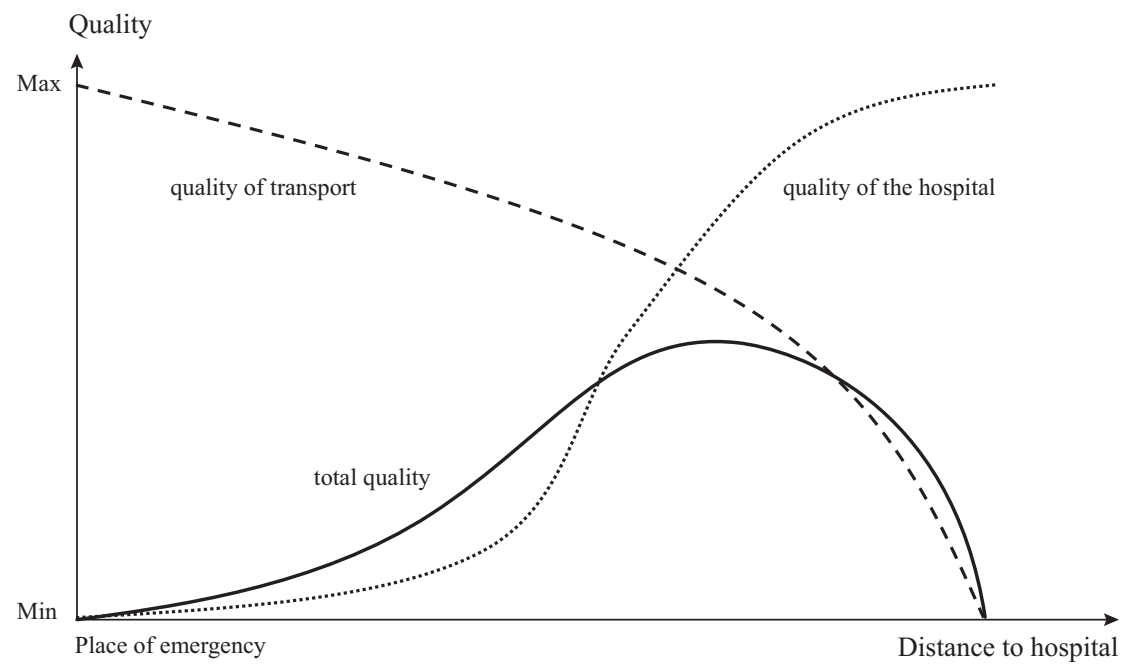

Figure 5. Quality of transport and in a healthcare facility (Source: own) 


\subsection{Accessibility}

Figure 6 demonstrates the principle of the friction of distance. ${ }^{11}$ It is a general principle that the number of transactions decreases with the distance between two individuals or centres. For instance, the higher the distance, the lower the number of visits. If the distance gets too high, the gravity of the two units is too low and the number of transactions is zero. The consequence for healthcare services is obvious: If healthcare services are too far away, people will not seek them. However, distances should not be measured in kilometres alone. Frequently, travel times differ strongly from pure kilometres, in particular when people have no private transport. Furthermore, the demanded service will determine the friction of distance. 30 minutes travel might seem long for a preventive service while it is easily covered once the patient suffers pain.

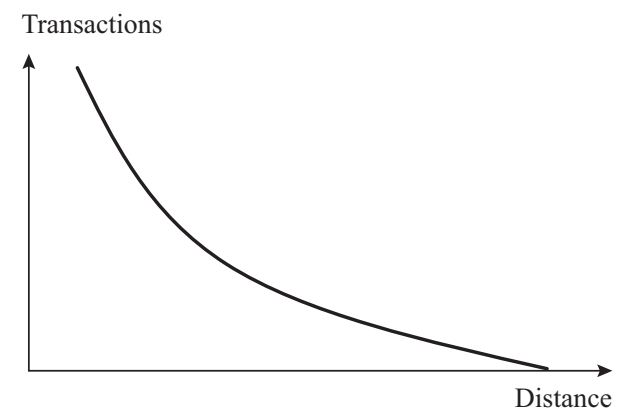

Figure 6. Friction of distance (Fleßa 2018)

Distance does not play a major role in centres with high population density, many healthcare facilities and good public transport. In rural, peripheral regions, however, distance might prevent people from seeking (early) help. They might die on the road to the healthcare facility and suffer from loneliness, as their relatives cannot visit them. Distance is a major problem in the periphery.

\subsection{Case study}

Consequently, we have a goal conflict in the magic triangle. The costs call for a concentration of services in few locations, quality in the facilities will require the same. However, quality during the transport and accessibility will require establishing and maintaining many more, smaller healthcare

11 P. Gould, The geographer at work (Oxford: Routledge, 2015). 
facilities all over the periphery. We would like to demonstrate the goal conflict between accessibility and cost with the example of obstetrics and paediatrics of hospitals in the North-East German district of VorpommernGreifswald. Until 31 ${ }^{\text {st }}$ December 2014, three hospitals (Greifswald, Anklam, and Wolgast) provided inpatient care for children and deliveries. ${ }^{12}$

Table 1 and Table 2 contrast the situation of 2014 for the case that paediatric and obstetric cases are treated in all three hospitals with the scenario that all cases are concentrated at the hospital in Greifswald. As expected (see section 2.2), the concentration has a major economic impact. While the two departments in the three hospitals generated a negative marginal contribution (MC) of about 3.6 million $€$ p.a., $\mathrm{MC}$ is positive and about 2.1 million $€$ if we concentrate. Centralisation sets resources free and generates about 5.7 million $€$.

Table 1. Paediatrics and obstetrics 2014, hospitals of Anklam,

Greifswald, and Wolgast (van den Berg et al. 2019)

\begin{tabular}{lrrrrrrr}
\hline & \multicolumn{3}{c}{ Paediatrics } & \multicolumn{3}{c}{ Obstetrics } & Total [€] \\
\cline { 2 - 8 } & beds & cases & MC $[\boldsymbol{\epsilon}]$ & beds & cases & MC $[\boldsymbol{\epsilon}]$ & \\
\hline Wolgast & 9 & 1057 & $-356,810$ & 5 & 357 & $-1,048,214$ & $-1,405,024$ \\
\hline Anklam & 5 & 496 & $-998,182$ & 5 & 280 & $-1,270,780$ & $-2,268,962$ \\
\hline Greifswald & 16 & 1820 & 171,927 & 11 & 800 & $-115,809$ & 56,118 \\
\hline \multicolumn{1}{c}{ Total } & 30 & 3373 & $-1,186,065$ & 21 & 1437 & $-2,434,803$ & $-3,617,868$ \\
\hline
\end{tabular}

Table 2. Paediatrics and obstetrics 2014, concentration on hospital Greifswald (van den Berg et al. 2019)

\begin{tabular}{|c|c|c|c|c|c|c|c|}
\hline & \multicolumn{3}{|c|}{ Paediatrics } & \multicolumn{3}{|c|}{ Obstetrics } & \multirow[t]{2}{*}{ Total $[€]$} \\
\hline & beds & cases & MC [€] & beds & cases & MC [€] & \\
\hline Wolgast & 0 & 0 & 0 & 0 & 0 & 0 & 0 \\
\hline Anklam & 0 & 0 & 0 & 0 & 0 & 0 & 0 \\
\hline Greifswald & 29 & 3373 & $1,281,188$ & 20 & 1437 & 806,408 & $2,087,597$ \\
\hline Total & 29 & 3373 & $1,281,188$ & 20 & 1437 & 806,408 & $2,087,597$ \\
\hline
\end{tabular}

12 N. van den Berg et al., "Economic efficiency versus accessibility. Planning of the hospital landscape in rural regions using a linear model on the example of paediatric and obstetric wards in the northeast of Germany," BMC Health Services Research 19, no. 1 (2019): 245. 
At the same time, quality calls for a centralisation in Greifswald. Assuming that a labour ward has to be staffed by one midwife for 365 days and 24 hours $(365 \times 24)$, at least five midwives have to be employed in each hospital providing obstetric services. For Wolgast, one midwife will support 1.37 deliveries per week, for Anklam 1.08 and for Greifswald 3.08. After concentration, the number of deliveries per midwife in Greifswald will be 5.53 , resulting in a routine that is five times as high as for Anklam. It is obvious that the low number of deliveries is quite risky, as critical incidents will occur too seldom and so they might not be handled properly.

However, accessibility clearly calls for a continuation of the paediatric and obstetric services in all three hospitals. As Figure 7 shows, the catchment areas of the hospitals as well as the driving distances of the population in the district strongly depend on the number of hospitals.

The first map shows the catchment areas of the three hospitals in 2014 just before paediatrics and obstetrics in Wolgast were closed. Nobody had to travel a distance of more than 40 minutes, and only few in the very East on the island of Usedom had distances longer than 30 minutes to the next hospital. After closing paediatrics and obstetrics in Wolgast, the situation changed (second map). The majority of the population of Usedom island has distances of more than 30 minutes to the next hospital. The third map indicates that many people in the south of the district will suffer longer access rates if the respective departments in Anklam were closed instead of Wolgast. Finally, the fourth map demonstrates the catchment areas if both small hospitals, Anklam and Wolgast, will not continue to run these two departments. It is obvious that the North-East of Usedom island will suffer. The access time in case of emergency will be higher than 40 minutes, for the small towns of Heringsdorf and Ahlbeck more than 60 minutes. As this island is a major touristic hot spot, access time might even increase due to traffic jams during summer.

It is obvious that accessibility, quality and costs are in a goal conflict. We can maximize accessibility if we establish and run as many healthcare facilities as possible. These units would have to be very small, and this has to be challenged. In these "mini-hospitals", we would neither attract professional staff willing to work there nor can they develop sufficient routine to upkeep quality. From a pure economic perspective, concentration on very few facilities would be appropriate. The German constitution calls for an "establishment of equivalent living conditions" (Art. 72 (2), GG) throughout Germany. However, it is obvious that this 
does not mean "identical living conditions" but "living conditions of equal value". The population in centres will always have more rapid access to healthcare providers, but we must safeguard that the population in peripheral regions has a minimum standard of accessibility, i.e., we need a compromise between accessibility, cost and quality. This compromise might not be satisfactory. Consequently, we have to seek for innovations that allow providing high quality and affordable healthcare services, which are still accessible for the population. The search for innovations in healthcare are, thus, the main instrument to reconcile the conflicting goals.
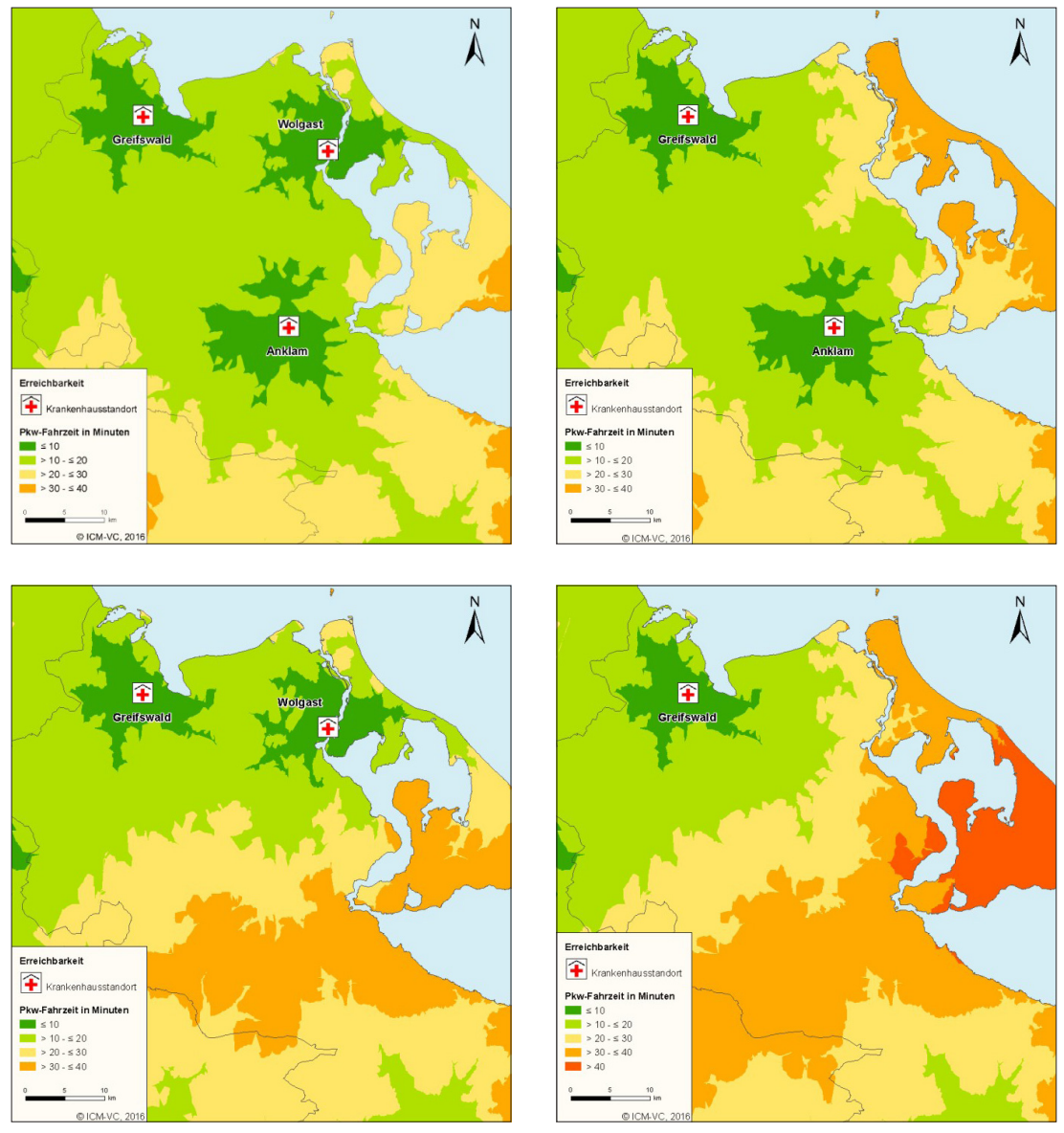

Figure 7. Accessibility of hospitals in the district of Vorpommern-Greifswald (van den Berg et al. 2019) 


\section{Innovations}

In this section, we will analyse a number of innovations of healthcare developed and implemented in the district of Vorpommern-Greifswald. This district is rather rural and very remote for German standards and the innovations focus on reconciling the conflict between costs, quality and accessibility. In the last section, we will investigate whether these innovations have the potential to spread within the Baltic Sea region.

\subsection{Telemedicine}

Traditionally, healthcare services are rendered in unity of time, place and action, i.e., the provider must meet physically with the patient. Telemedicine breaks this unity and permits that the service provider and the patient are at different places. ${ }^{13}$ For instance, tele-radiology implies that the imaging (e.g. x-ray, CT-scan or MRI) is made in a small rural hospital, while the radiologists "reads" the images in a major hospital in a different place. Imaging does not require a professional radiologist; thus, it can be performed by a radiographer assistant in the smaller hospital. The equipment must be in place, but the depreciation of even expensive radiological equipment is cheap in comparison to the salary of five radiologists who are required to provide the full services $365 \times 24$.

Tele-radiology has major advantages. Firstly, the costs are strongly reduced. Small hospitals have an insufficient number of images per year to allow uninterrupted $365 \times 24$ presence of a radiologist. It is much more efficient to use the services of the radiologist from another hospital. Secondly, the quality of services will increase. Due to his higher workload, the radiologist in the major hospital develops a much greater routine than the radiologist in a small hospital. As radiologists usually sit in separate rooms and have very little patient contact, it does not make a difference for the patient whether "reading" is done within the small hospital or in a different place in a major hospital. Thirdly, it becomes more and more difficult to fill vacant positions of radiologists in rural hospitals. Thus, tele-radiology might be the only way to make radiological service accessible in rural places.

The example shows the impact of innovations: Without tele-radiology, there is a major goal conflict between costs, quality and accessibility. We would like to have a team of radiologists working in each hospital $365 \times 24$ in order to provide accessible services to the population in the catchment

13 S. Gogia, "Fundamentals of Telemedicine and Telehealth," Academic Press (2019). 
area of the remote hospital. Accessibility calls for a radiological department working 365 days a year and 24 hours a day in each hospital irrespective of its size. However, this will result in very high unit costs per imaging procedure. Thus, costs call for closing-down radiological departments in small hospitals. Instead, patients requiring imaging will have to be transported to major hospitals. However, this will constitute a major quality issue. Transporting patients is cumbersome, dangerous and expensive. Most likely, closing-down a radiological department will finally lead to situations where patients requiring imaging will not get it. Thus, quality calls for the maintenance of these departments and conflicts with costs.

Tele-radiology can overcome this goal conflict. It reduces costs and improves quality as well as accessibility at the same time. The telemedical provider can be even on another continent if language barriers are no problems. For instance, small hospitals in the USA use radiologists in India, but in Germany the provider must be capable to reach the patient within 60 minutes. Consequently, the university hospital of Greifswald has become the telemedical centre for the hospitals in the district of VorpommernGreifswald and Vorpommern-Rugen. ${ }^{14}$ The services even stretch beyond the border and include hospitals in the North-West of Poland. A real teleradiological network has been developed permitting $365 \times 24$ radiological services in all hospitals in this peripheral region. ${ }^{15}$

Other examples of telemedicine utilized in the district of VorpommernGreifswald are tele-pathology and tele-monitoring. ${ }^{16}$ Many small hospitals have operating theatres, and some surgical procedures require a pathologist performing a rapid incision examination of a sample. However, small hospitals do not have a workload to support the salary of a pathologist. Instead, the sample is put under a digital microscope and the image is transferred to the pathologist in a major hospital. He sees the sample in his microscope just as he would if the sample was with him. Again, the disadvantage of the rural place is overcome by this innovation and the university hospital has become a telemedical centre.

14 N. Hosten, "Grenzenlos Netzwerken: Deutsch-polnisches Telemedizinprojekt in der Euroregion Pomerania."

15 C. Rosenberg et al., "Teleradiology from the provider's perspective - cost analysis for a mid-size university hospital," European radiology (2013): 1-9.

16 S. Ribback et al., "Virtual slide telepathology with scanner systems for intraoperative frozen-section consultation," Pathology-Research and Practice 210, no. 6 (2014): $377-382$. 
Germany just passed a law fostering the development of telemedical services (Krankenhauszukunftsgesetz). The district of VorpommernGreifswald will develop a proposal including telemedical emergency care for paediatric patients in hospitals without a paediatrician. The specialist will support the emergency department in the small hospital where a general physician examines the child. Another component, which will be included, is the tele-monitoring of patients with chronic heart failure.

Consequently, the district develops a compressive system of telemedical services in order to reconcile the conflicting goals. The district is definitely not the only area where these services are offered, but it has a high degree of integration between the smaller hospitals and the maximum level hospital. This high degree of integration might be an innovation seedling for other regions where telemedicine services are frequently no network between different institutions but one-by-one agreements focusing only on one kind of telemedical services.

\subsection{Telemedicine emergency doctor services}

A special application of telemedicine is the telemedicine emergency doctor service system, which was implemented in the district of Vorpommern-Greifswald since 2017 in order to provide high quality emergency services in this lowly populated peripheral region. In Germany, emergency medical service (EMS) is provided by paramedics (1-3 years of training) and emergency physicians. Paramedics are located in quite a number of places all over the district, while emergency doctors are scarcer and have only few centrecentres. Once an emergency call reaches the dispatcher, he decides whether merely paramedics are sent or whether an emergency doctor is needed additionally. If both are required, paramedics and emergency physicians are transported independently in separate vehicles to the emergency site in the so-called "rendezvous system". ${ }^{17}$

This system has a number of disadvantages in rural peripheral regions with low population density. Emergency doctors are scarce and cannot be located in a dense network of stations waiting most of the time for a few emergency calls. However, each place in the district should be accessibly

17 V. Lischke et al., "Verbessert das Rendezvoussystem die rettungsdienstliche Versorgungsqualität?," Intensivmedizin und Notfallmedizin 39, no. 5 (2002): 448-456; P. Pfütsch, "Das Notfallsanitätergesetz," in Notfallsanitäter als neuer Beruf im Rettungsdienst. Ein Überblick über Entwicklungen und Tendenzen, ed. P. Pfütsch (Wiesbaden: Springer, 2020): 19-24. 
for an emergency doctor within a short period as this might save the life of the emergency case. The paramedic is well trained, but due to strict regulations, he is not permitted to perform certain procedures without the supervision of a medical doctor. Thus, efficiency and quality of care are conflicting goals. Even if funds were not limited, new emergency doctor stations scattered all around the countryside would not be helpful as it would be impossible to find emergency doctors willing to work in these rural places and have only few emergencies per day.

In this situation, the district of Vorpommern-Greifswald implemented the tele-emergency doctor (TED) system. This innovation is not completely new in Germany but it had never been implemented in a rural district. ${ }^{18}$ A TED is an emergency doctor who works from a telemedical office, which is connected all the time with the ambulance car and the paramedics in case of an emergency. Paramedics contact the emergency doctor via telemedicine. The tele-emergency doctor is provided with vital signs (e.g. ECG) in real time and talks to the paramedic. Furthermore, he sees the patient via a camera and can talk to him. Consequently, he gives advice, delegates drugs and supervises the interventions of the paramedic. ${ }^{19}$

The tele-emergency doctor system was implemented in the district in 2017. ${ }^{20}$ Until today, some 45,000 emergencies were supported by the teleemergency doctors. The results are very promising, as a medical evaluation

$18 \mathrm{~S}$. Bergrath et al., "Technical and organisational feasibility of a multifunctional telemedicine system in an emergency medical service-an observational study," Journal of telemedicine and telecare 17 no. 7 (2011): 371-377; S. Bergrath et al., "Implementation phase of a multicentre prehospital telemedicine system to support paramedics: feasibility and possible limitations," Scandinavian journal of trauma, resuscitation and emergency medicine 21 no. 1 (2013): 54; J. Brokmann et al., "Potenzial und Wirksamkeit eines telemedizinischen Rettungsassistenzsystems." Der Anaesthesist 64, no. 6 (2015): 438-445.

19 Deutsche Gesellschaft für Anästhesiologie und Intensivmedizin, "Telemedizin in der prähospitalen Notfallmedizin: Strukturempfehlung der DGAI," Anästh Intensivmed 57 (2016): 2-8.

20 B. Metelmann and C. Metelmann, "Mobile Health Applications in Prehospital Emergency Medicine. Mobile Health Applications for Quality Healthcare Delivery," in Mobile health applications for quality healthcare delivery, ed. A. Moumtzoglou (Hershey, Pennsylvania: IGI Global, 2019): 117-135; C. Prasser et al., "Der Telenotarzt als Innovation des Rettungsdienstes im ländlichen RaumKosten der Implementierung," Gesundheitsökonomie \& Qualitätsmanagement 25, no. 3 (2020): 150-156. 
clearly showed that the treatment by TEDs is safe and that there is a high satisfaction among all involved groups (paramedics, emergency doctors, emergency dispatcher, and patients). ${ }^{21}$

As stated above, the TED-innovation is not completely new, but it was never implemented in a rural district. This example reveals the meaning of an innovation. It is not the invention (i.e. the very first time that a new idea or good is conceived), but the process of adopting and adapting this invention to another situation or environment which frequently becomes the door opener for success. TEDs were first used in rural settings in order to improve the quality of services. This is the original invention, and it is important. However, the application of the concept in rural areas (requiring some adaptions of the original concept to take care of the special situation, such as poor net coverage) makes it a death-or-life-question. The adapted concept seems to be much more important than the original application and has a much higher potential to be relevant for other areas and countries. The state of Mecklenburg-Western Pomerania (where Vorpommern-Greifswald is situated) just decided to extend the concept to other districts.

\subsection{Drones}

Drones in healthcare are another innovation that can reduce the problems of rural peripheral regions. Drones are very fast and can transport equipment or materials from one place to another faster than any other means of transport. They do not require roads or rails. Thus, they are ideal transport vehicles for automatic external defibrillators (AED), laboratory and pathology samples as well as human blood. They can be used to transport materials from one fixed point of care (e.g. hospital) to another fixed point of care (e.g. external laboratory) or to any place (e.g. place of emergency). ${ }^{22}$

The district of Vorpommern-Greifswald has started a pilot phase for the drone-based transport of blood and AEDs. The AED is stationed in the university hospital in Greifswald. If the partner hospital in Wolgast requires blood from the blood bank in Greifswald, it is transported by a drone.

21 R. Plum et al., "Patientenzufriedenheit im Rettungsdienst - Ein Vergleich nach Versorgung mit und ohne Telenotarzt," Anästhesiologie \& Intensivmedizin 03 (2020): 40.

22 B. Hiebert et al., "The Application of Drones in Healthcare and Health-Related Services in North America. A Scoping Review," Drones 4, no. 3 (2020): 30. 
A car requires about 35 minutes for the distance of $31 \mathrm{~km}$. The drone covers the euclidean distance of $25 \mathrm{~km}$ within less 25 minutes. The difference does not seem very impressive. However, the hospital of Wolgast is on the main road to the tourism island of Usedom. During tourism season, long traffic jams are frequently blocking the road so that the transport from Greifswald to Wolgast can take more than an hour on the road. This can make a major difference in the survival probability of a patient in Wolgast hospital.

An automated external defibrillator is a medical device that analyses the heart rhythm. In case of ventricular fibrillation if delivers an electric shock to restore the heart rhythm to normal. In urban areas, AEDs are accessible in many public places. However, in rural places, the next AED might be too far away and the emergency paramedic might need quite some time to reach the place of emergency. ${ }^{23}$ Consequently, drone-based AED transports are ideal for rural peripheral regions. Once the emergency dispatcher is informed about the emergency with a cardiac arrest or other heart problems, he does not only send the emergency car, but also a drone with an AED. As most phone calls in rural areas are sent from mobile phones, the dispatcher knows exactly the coordinates of the emergency. Within a few minutes the AED is in place and it can be applied easily by a layperson.

Is this innovation really new? Similar system in particular for the transport of drugs were developed and used in African countries at least five years ago. Rural health centrecentres in Rwanda received drugs and blood delivered by drones and on parachutes as they were not accessible due to road and weather conditions. ${ }^{24}$ However, German aviation laws have prohibited the adoption of this innovation. Consequently, the pilot project in the district of Vorpommern-Greifswald did not only implement a technical solution, but it involved lawyers to safeguard that all laws and regulations are adhered. Furthermore, an analysis of the acceptability of drones for the population was analysed. Thus, we realise that the innovation potential of this pilot in Vorpommern-Greifswald is not the technique of the drones, but their managerial, legal and social implementation.

23 A. Pulver, R. Wei and C. Mann, "Locating AED enabled medical drones to enhance cardiac arrest response times," Prehospital Emergency Care 20, no. 3 (2016): 378-389.

${ }^{24}$ E. Ackerman and E. Strickland, "Medical delivery drones take flight in east Africa," IEEE Spectrum 55, no. 1 (2018): 34-35. 


\subsection{Cross-Border healthcare}

Borders reduce the welfare of people. This is in particular the case in healthcare as borders prohibit that healthcare providers serve the patients living next to them. In many cases, people have to travel long distances to reach a provider on their side of the border although a provider is much closer on the other side. Even when political borders do not constitute a barrier, cultural (in particular language!) and financial borders are a major cause of poor healthcare in border regions. ${ }^{25}$

The island of Usedom is a good example for the negative consequences of borders. The island is divided between a major German and a smaller Polish part. As shown in Figure 7, the German part does not have a hospital and people seek inpatient healthcare services at the hospital of Wolgast. Before the end of World War II, Wolgast did not have a hospital and the entire population of Usedom used the hospital in Świnoujście (Swinemünde) as it belonged to Germany. After the new border was established, the population of the German part had to go to Greifswald or Anklam. Consequently, a new hospital was built in Wolgast. Accordingly, political borders are a major reason for long distances to healthcare providers in the border region.

Today, patients from Usedom would be warmly welcome in the hospital of Świnoujście. This would be convenient in particular for deliveries and paediatrics after the respective departments were closed in Wolgast hospital end of 2014. However, the number of patients seeking healthcare in Poland is very small.

This has a number of reasons ${ }^{26}$ :

Language: Only very few inhabitants of the German part of Usedom speak Polish. The number of Polish citizens living in the West Pomeranian Voivodeship (Polish province in the North-West) who can speak German is much higher, but as healthcare services are organized centrally in Poland this does not guarantee that doctors, midwives and nurses working in Świnoujście hospital are from this area and speak German. Most Germans would not appreciate a healthcare service rendered in a foreign language, definitely not in Polish.

25 S. Fleßa, Wirtschaftliche Grundlagen der grenzüberschreitenden Versorgung (Berlin: Medizinisch-Wissenschaftliche Verlagsgesellschaft, 2013).

26 W. Ried and P. Marschall, "Potential benefits of crossborder health care: The case of Poland and Germany," Economics \& Sociology 9, no 3 (2016): 14. 
Quality: Many Germans assume that the quality of care rendered on the Polish side of the border is lower than on the German side. It is a matter of fact that Polish hospitals are frequently not as well equipped and modern as German institutions. However, the training of staff is on a comparable standard, sometimes even above the German standard. For instance, emergency paramedics in Poland have to study and earn a Bachelor's degree in Emergency Care, while Germany just recently introduced a technically three-year course building on 10 years of school education. Before, many German emergency paramedics had only a 1-2 years training on the job. The assumption that the quality of services is better in Germany than in Poland is definitely not correct in all instances.

Cost: Many Germans fear that the costs of healthcare services are not paid for if they seek healthcare in Poland. Based on "EU-Directive 2011/24/ EU of the European Parliament and the Council of 9 March 2011 on the application of patients' rights in cross-border healthcare", all costs of emergency treatment are covered by $100 \%$. If a German patient seeks healthcare abroad without an emergency, the German health insurance covers the costs that it would have paid in Germany. As Polish healthcare services are still much cheaper than German services, there is no risk that Germans will have to pay out of their own pocket. However, the fear might not be rational, but it has an impact on people.

The district of Vorpommern-Greifswald and the Pomeranian Voivodeship have intensified cross-border healthcare in a special field, cross-border emergency care. Until recently, the transport of patients in an ambulance care from one side of the border to the other was prohibited. Instead, patients had to be brought to the border where they were transferred to another ambulance from the other side of the border. It took years until direct patient transport was permitted. However, until today the airborne rescue and patient transport services are not allowed to cross the border.

The legal limitations of cross-border emergency care are only one major obstacle. The main problem is the language. Consequently, the Pomeranian Voivodeship and the district of Vorpommern-Greifswald have trained all emergency paramedics and emergency doctors in the other language. At least, they are able to ask specific questions on the health conditions and understand the respective answers. They also undergo a joined (simulation) emergency training in order to improve cooperation and understanding. A new project will start in 2021 focussing on the complete emergency chain including the emergency departments of hospitals. 
The barriers of the border between Germany and Poland are stronger than for many other regions. For instance, most of the problems mentioned here are unknown at the border between Germany and the Netherlands. However, they might also exist between some other countries in the Baltic Sea region so that the experiences in Vorpommern-Greifswald might again constitute an innovation seedling for the region.

\section{Adopting innovations in the Baltic Sea region}

Innovations first occur in a certain place and diffuse to centres and periphery. ${ }^{27}$ In the case of healthcare, it is relevant to ask how innovations of health services diffuse and under what conditions they are adopted or rejected in certain areas. In other words: What is the likelihood that the innovations presented in the last section will become a standard throughout the entire Baltic Sea region (and beyond)? In the next sub-section, we will develop a model of innovation adoption and analyse the factors influencing the adoption process.

\subsection{A model of innovation adoption}

Figure 8 exhibits a model of the adoption of health innovations. Furthermore, it allows the identification of barriers and their influence on the adoption process as well as the appropriate placement of available instruments in order to overcome those. ${ }^{28}$

The analysis starts with the functionality of the existing standard of diagnosis and treatment. ${ }^{29}$ The more stable the current system, the less likely of a novelty will be successful introduced. When initial shortcomings of the system are perceived, the first approach will always be to maintain it as long as possible. Compensatory measures create a kind of artificial stability, a so-called meta-stability. ${ }^{30}$ Only when this stabilization is no longer sufficient, the pressure for finding alternative solutions

27 T. Reichart, Bausteine der Wirtschaftsgeographie. Eine Einführung (Bern, Stuttgart, Wien: Haupt, 2008).

28 S. Fleßa, Gesundheitsreformen in Entwicklungsländern: eine kritische Analyse aus Sicht der kirchlichen Entwicklungshilfe (Frankfurt am Main: Lembeck, 2002).

29 S. Fleßa and W. Greiner, Grundlagen der Gesundheitsökonomie. Eine Einführung in das wirtschaftliche Denken im Gesundheitswesen (Berlin, Heidelberg: Springer, Gabler, 2013).

30 W. Ritter, Allgemeine Wirtschaftsgeographie. Eine systemtheoretisch orientierte Einführung (München: Oldenbourg, 2001). 
becomes more dominant and the probability of adopting an innovation increases measurably. The innovation process proves to be risky and complex so that systematic planning is necessary in order to overcome barriers. ${ }^{31}$

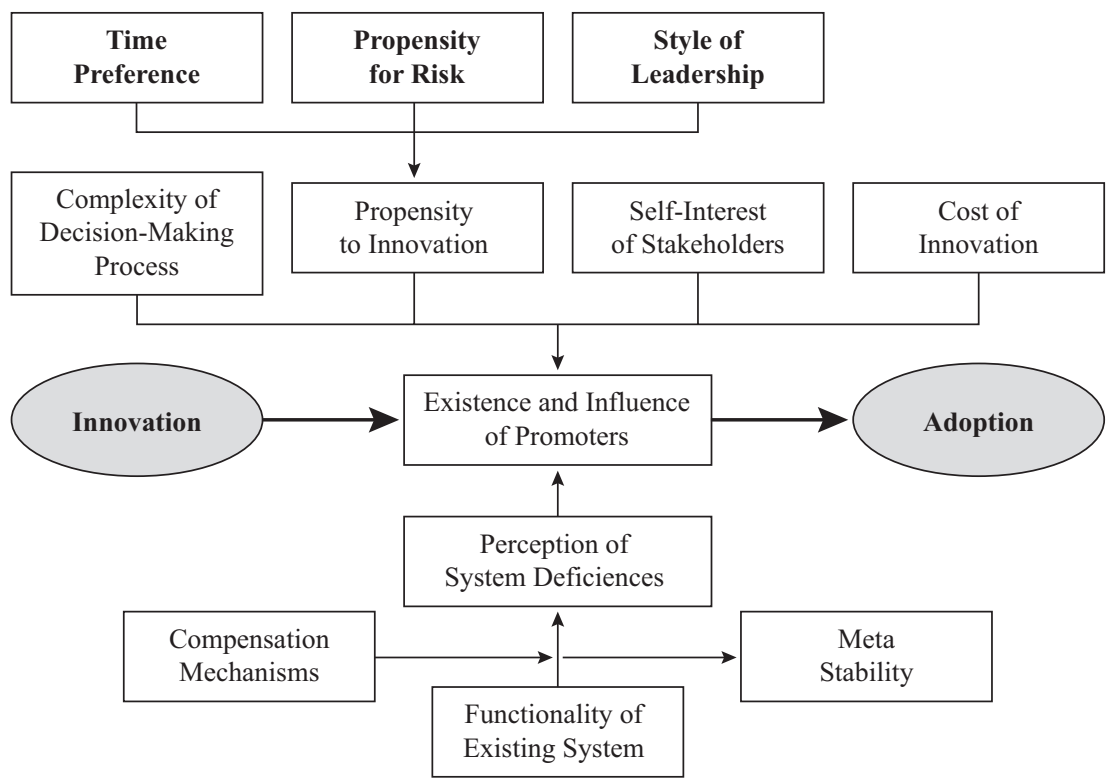

Figure 8. Model of Adoption of Healthcare Innovations (Fleßa 2002)

Consequently, the way that organizations and societies deal with shortcomings follows a certain pattern. It is almost impossible to adopt an innovation if the existing system works extremely well. Only if the current solution has shortcomings or meets limitations, organizations and societies are willing to invest resources in the development of alternative problem solutions. If a system suffers from poor functionality, however, the likelihood that promoters will be willing to invest in the search for new solutions is much higher. At the end of this process, we will have an invention, such as a new idea, paradigm, managerial system, technique or good. The implementation of the invention in the process will require the adaption of many

31 S. Auffermann and E. Staudt, Der Innovationsprozess im Unternehmen - eine erste Analyse des derzeitigen Stands der Forschung (Bochum: IAI, 1999). 
other systems, i.e., it will induce risks and costs. Consequently, most leaders first seek to improve the existing system instead of changing towards the invention. Frequently, societies subsidize old industries in order to avoid a complete system change. This works well for some time, but the old system regimes can only survive as long as they are protected. They become inflexible and meta-stable. ${ }^{32}$

The invention will not be forgotten, but it can mature in a niche. Many might overlook it, but it can develop in this niche until it has overcome childhood diseases and is ready to diffuse as standard solution. Here it is an innovation potential or innovation seedling. As soon as the current standard solution has come to its end and can no longer be stabilized, the innovation seedling is ready to sprout and become the new and better standard. ${ }^{33}$

However, the process to developing inventions, giving them room to mature as innovations seedlings and finally adopting them as new standard depends on the existence of key persons, so-called promoters. ${ }^{34}$ The ability and willingness to promote the adoption of an innovation depends on a number of factors. The first one is the complexity of decision-making. If there are only a few interest groups concerned by the novelty and only bilateral relations can be observed, the adoption process is comparatively simple. The more levels of a system are affected by the introduction of an innovation, the complexity of the decision making increases as well. ${ }^{35}$

The propensity towards innovation of promoters and other stakeholders is a crucial factor as well. It mainly depends on their respective time preference, the individual risk preference and the management concept within the organizations involved. The former is largely explained by the scarcity of resources, especially financial ones. The volume of funds available for a specific period is limited. Innovations always mean an investment. Refinancing occurs on the one hand under high uncertainty and on the other hand in future business periods. Financial expenditures being invested in research, development and market introduction of innovative products reduce the volume of funds available for present consumption. Different people show differing preferences with respect to how much

32 Ritter (2001)

33 M. Leder, "Innovationsmanagement - ein Überblick," Zeitschrift für Betriebswirtschaft Ergänzungsheft 1 (1989): 1-54.

34 J. Hauschildt et al., Innovationsmanagement (München: Vahlen 2016).

35 Fleßa and Greiner (2013). 
they are willing to invest in innovation research. The higher the willingness of all stakeholders for investments of this nature, the higher is their inclination towards innovation. Due to the high degree of uncertainty about success, the promoters' individual risk preferences are a key factor as well. Risk averse people tend to avoid uncertain investments. Consequently, people of a risk-taking nature have an encouraging effect on the innovation process. Additionally, the leadership style within the organization influences the propensity to innovate. An innovation-promoting structure has a positive effect on the entire innovation process. ${ }^{36}$ The groups of stakeholders have differing goals that they pursue individually. Those mostly origin from strategies within their respective institution. The individual goals of all interest groups must be identified, analyzed and coordinated in order to avoid contradicting strategies and thus hindering the adoption of the novelty. ${ }^{37}$

Due to the scarcity of resources, financial factors are of high importance. The term innovation costs includes expenses over the entire innovation process, ${ }^{38}$ i.e., expenditures for all sub-processes of research and development as well as spending on production, market introduction and sales. Costs emerge throughout the entire innovation process. The financing of research and development activities as well as the determination of the selling price and the negotiation of reimbursement with the health insurers depend on the level of total costs. The higher the costs of an innovation, the more challenging it is to adopt it as a standard solution.

Summarizing, we can state, that the adoption of a healthcare innovation from another region depends on a number of factors:

- Functionality of existing healthcare system.

- Personal characteristics of potential promoters, including personal interests.

- Costs of innovations.

- Complexity and tradition of existing systems.

36 S. Fleßa, Grundzüge der Krankenhausbetriebslehre (München: Oldenbourg, 2014); D. Vahs and A. Brem, Innovationsmanagement. Von der Idee zur erfolgreichen Vermarktung (Stuttgart: Schäffer-Poeschel Verlag, 2015); Hauschildt et al. (2016).

37 N. B. Heyen and T. Reiß, "Das Gesundheitswesen aus Innovationssystemperspektive. Acht Thesen und Handlungsmöglichkeiten: Teil 1," Sozialer Fortschritt 63 (2014): 245-252.

38 Fleßa (2014). 


\subsection{Barriers: differences in systems and funding}

The diffusion of innovations from one region to another requires an adoption process of the original innovation in order to fit to the system, financing, culture and traditions of the new region.

The majority of Germans is covered by a social health insurance (Bismarck system) for in- and outpatient services. Most services are provided by independent enterprises. About $1 / 3$ of hospitals is owned by Governments of the states, the districts or the municipalities, but run like independent business units irrespective of their trustees. Exemptions of this market-oriented system in Germany are emergency and prevention services. While the latter is in the hands of Government institutions, emergency services are usually provided by non-governmental and private for-profit organisations. The administration and organisation of emergency services is usually carried out under the leadership of the district commissioners. With a gross national product of about 51,000 US\$ p.a. p.c. and health expenditure of about 5,500 US\$, the German healthcare system is based on high resources.

Denmark, Norway, Finland and Sweden have national gealthcare services with a strong role of the Government as provider of healthcare services as well as of social protection. Central planning (e.g. hospital planning in Denmark) is much stricter than in Germany, and many physicians are employed by the Government. Emergency services are, consequently, organized and rendered by Government institutions with a certein degree of regional independence. The resources are rather similar to Germany, while Norway has higher healthcare resources and Finland lower than Germany.

Finally, there are several countries in the Baltic Sea region, which have been transformed from former Soviet Union system to social insurances within a few years. Estonia, Latvia, Lithuania, Russia and Poland have liberalized their healthcare systems to different degrees. While the Baltic countries successfully privatized the service provision, most citizens in Russia and Poland still use Government services paid for by the national health insurances. Emergency services are usually provided and organized by the central Government. The resources are much lower, with a minimum in Russia and Latvia (about $1 / 4^{\text {th }}$ of the German statistics).

Consequently, the different set-up of the healthcare system constitutes a major barrier for the transfer of innovations in healthcare. The innovations 
described in section 3 might be innovation seedlings for other countries facing similar healthcare challenges in rural areas. A strongly marketoriented system would produce entrepreneurs willing to risk adopting an innovation. However, central Government systems will require knowing country-specific administration rules and overcoming bureaucratic barriers.

Furthermore, the innovations described above might simply be too expensive for countries with fewer resources. However, the diffusion of telemedicine, in particular in Estonia, clearly indicates that a country can be highly innovative even with very few resources.

Table 3. Baltic Sea region - basic statistics ${ }^{39}$

\begin{tabular}{lcccc}
\hline Country & $\begin{array}{c}\text { GNI per capita, } \\
\text { PPP (current } \\
\text { international \$) }\end{array}$ & $\begin{array}{c}\text { Population } \\
\text { density (people } \\
\text { per sq. km of } \\
\text { land area) }\end{array}$ & $\begin{array}{c}\text { Domestic general } \\
\text { government } \\
\text { health expendi- } \\
\text { ture per capita, } \\
\text { PPP (current } \\
\text { international \$) }\end{array}$ & $\begin{array}{c}\text { Current health } \\
\text { expenditure } \\
\text { per capita, } \\
\text { PPP (current } \\
\text { international \$) }\end{array}$ \\
\hline Denmark & $55,560.00$ & 137.29 & $4,284.34$ & $5,092.98$ \\
\hline Norway & $64,760.00$ & 14.45 & $5,281.01$ & $6,203.45$ \\
\hline Finland & $46,480.00$ & 18.12 & $3,181.09$ & $4,112.05$ \\
\hline Sweden & $52,190.00$ & 24.69 & $4,498.22$ & $5,386.73$ \\
\hline Germany & $50,910.00$ & 235.71 & $4,625.85$ & $5,463.33$ \\
\hline Estonia & $32,790.00$ & 30.31 & $1,499.00$ & $1,987.72$ \\
\hline Latvia & $28,170.00$ & 31.24 & 868.49 & $1,589.69$ \\
\hline Lithuania & $31,920.00$ & 45.15 & $1,297.79$ & $1,978.27$ \\
\hline Russia & $25,080.00$ & 8.82 & 757.03 & $1,329.29$ \\
\hline Poland & $28,690.00$ & 124.02 & $1,243.75$ & $1,784.40$ \\
\hline
\end{tabular}

39 World Bank, “World Development Indicators.” Retrieved 20.11.2020, 2020, from Source: https://databank.worldbank.org/source/world-development-indicators. 


\section{Discussion}

The case studies presented in this paper indicate that a number of healthcare innovations exist in the district of Vorpommern-Greifswald. They might find their way to become a standard in the rest of Germany, in the Baltic Sea region and elsewhere. However, they might also face financial, legal or cultural barriers. In many cases, they will be rejected just because they were invented elsewhere ("not-invented-here syndrome", $\mathrm{NIH}) .{ }^{40}$

At the same time, many innovations were developed in other locations, which do not find their way to the German healthcare system. For instance, Denmark restructured its hospital system completely in the last decade with tremendously good results. ${ }^{41}$ This innovation finds extremely high resistance in Germany. The administrative reform in 2007 based systematic regional hospital planning on nationally agreed-on criteria and reduced the number of hospitals with emergency care units from 40 to 21, Germany still has a very high density of small hospitals without sufficient routine and equipment to treat certain diseases. However, the fact alone that this reform was extremely successful in Denmark does not convince German hospital planners and politicians. In addition, even if these two groups were determined to learn from Denmark, the population living in the catchment areas of these small German hospitals seems to be much less willing to accept Government decisions than in Denmark. Any attempt to close smaller hospitals leads to the civil unrest. There seems to be a different culture of accepting Government regulations and decisions prohibiting the hospital planning innovation to diffuse to Germany.

Digital health records are another innovation that finds strong resistance in Germany. Estonia established a comprehensive digital health system in $2004^{42}$ with an e-health roadmap, a national health information system, e-prescriptions, e-consultations, digital ambulances and decision-support systems for doctors. Almost all citizens have a digital health record accessible

40 D. Antons and F. T. Piller, "Opening the black box of "Not Invented Here". Attitudes, decision biases, and behavioral consequences," Academy of Management Perspectives 29, no. 2 (2015): 193-217.

41 T. Christiansen and K. Vrangbæk, "Hospital centralization and performance in Denmark - ten years on," Health Policy 122 no. 4 (2018): 321-328.

42 H. Taal, "Health in the digital society: the experience of Estonia," European Journal of Public Health 28, suppl. 4 (2018): cky213. 014b. 
all over the country by any healthcare provider treating the patient. This rapid availability of healthcare data reduces double diagnoses, improves the quality of treatment and cuts costs. ${ }^{43}$ It seems that the Estonian population has no fear that their healthcare data is abused. Germany, however, called for digital healthcare in 2004 (GKV-Modernisierungsgesetz), but it was not introduced until today. The existing cards hardly hold more information than the name of the patient and his insurer. Digital prescriptions, records of diagnostic results, drugs and treatments have been prohibited by strict data confidentiality regulations and laws. An innovation which is highly successful and which could be implemented in Germany easily is rejected due to a different understanding of confidentiality and different laws.

A last example is the training and role of nurses. While nurses have been trained academically in many countries of the Baltic Sea region for decades, Germany just started university courses for nurses. Since the early $1990^{\text {th }}$, nursing administration was taught at colleges, but practical nursing has always been a technical training in Germany while nurses were trained at universities in Scandinavia for a long time. ${ }^{44}$ Consequently, nurses have a much higher knowledge and are permitted to perform a much wider range of services in these countries than in Germany. Consequently, the Nurse Practitioner is a reality in many countries of the world, ${ }^{45}$ while German laws restrict the services of nurses to few activities of daily living. Physicians might delegate some tasks to nurses, but they must not be substituted by them, not even in rural areas where the density of doctors is comparably low. This innovation and decades of experiences in Scandinavia are readily waiting to be adopted in Germany, but in particular strong lobby groups of German physicians invest hard effort to avoid it.

These examples show that there is a great need for exchange of ideas and innovations within the Baltic Sea region. There are scores of innovations waiting to be adopted in other countries. This will usually require an adaption process in order to fit to the historical pathway and the culture of people, but the process must not be blocked. We need more freedom

43 T. Habicht et al., "Estonia: health system review," (2018).

44 I. Kapborg, "Nursing education in Sweden. Development from vocational training to higher level education," Journal of Advanced nursing 27, no. 2 (1998): 372-378.

45 E. Jangland et al., "The development of a Swedish Nurse Practitioner Program-a request from clinicians and a process supported by US experience," Journal of Nursing Education and Practice 4, no. 2 (2013): 38-48. 
of mobility. Mobility of workers who bring new ideas. Mobility of innovations increasing the effectiveness and efficiency of healthcare systems. Moreover, mobility of research and researchers so that innovation seedlings from one region become problem solutions for another region.

\section{Inovācijas veselības aprūpes jomā perifērajos reǵionos: Greifsvalde kā Baltijas jūras reǵiona inkubators?}

\section{Kopsavilkums}

Šajā publikācijā kā veselības aprūpes sistēmas pamatmērḳu sistēma ir aplūkots "burvju trīsstūris", ko veido izmaksas, kvalitāte un pieejamība. Tajā ir arī sniegts ieskats par Forpomernas-Greifsvaldes regíionā īstenotajām inovācijām. Visbeidzot, publikācijā ir aplūkots inovāciju pieņemšanas modelis un potenciāls uzsākt to pieņemšanas un pielāgošanas procesu Baltijas jūras reǵionā.

No veselības aprūpes sistēmām tiek gaidīts, ka tās spēs īstenot vismaz trīs pretējus mērķus: nodrošināt iedzīvotājiem pietiekamu atbilstošas kvalitātes veselības aprūpes pakalpojumu apjomu, saglabāt izmaksas pieejamā līmenī un nodrošināt pakalpojumu pieejamību ikvienam sabiedrības loceklim. Vienlaicīga visu šo mērķu sasniegšana reizēm var šksist kā mēǵinājums pārveidot apli par kvadrātu, proti, lai kvalitatīvi pakalpojumi būtu pieejami ikvienam, tostarp iedzīvotājiem, kas mīt perifērajos reǵionos, ir nepieciešami resursi, turklāt rodas izmaksas, kuras bieži vien daudziem politiķiem un sabiedrības locekḷiem šķiet neatbilstošas. Vienlaikus augstas kvalitātes pakalpojumi ir pieejami tikai centralizētās sistēmās, kur gana liela pacientu skaita dēl ir iespējams izveidot pietiekamu rutīnu. Tomēr šñ centralizācija arī nozīmē, ka dažkārt pakalpojumi nav pieejami, jo īpaši lauku reǵionos. Tāpēc vienīgā iespēja ir inovāciju īstenošana veselības aprūpes nodrošināšanā, kas uzlabotu sistēmas efektivitāti un dotu iespēju vienlaikus sasniegt visus mērķus.

Forpomernas-Greifsvaldes reǵionā ir izstrādātas, pieņemtas un īstenotas inovācijas telemedicīnas, neatliekamās palīdzības pakalpojumu, bezpilota lidaparātu un pārrobežu veselības aprūpes jomā, kas reǵionā jau ir pierādījušas savu lietderīgumu. Šīs inovācijas ir iespējams izplatît citās 
Baltijas jūras reǵiona valstīs. Turklāt no citām valstīm aizgūtas inovācijas var kḷūt par auglīgiem inovāciju iedīgliem Ziemeḷrietumvācijas reǵionā. Tomēr šim nolūkam, lai uzlabotu situāciju veselības aprūpes jomā pat perifērajos reǵionos, būtu nepieciešams pārvarēt vairākus finanšu, kultūras un personiskos šḳēršlıs.

Šajā publikācijā kā veselības aprūpes sistēmas pamatmērḳu sistēma ir aplūkots "burvju trīsstūris", ko veido izmaksas, kvalitāte un pieejamība. Tajā ir arī sniegts ieskats par Forpomernas-Greifsvaldes regínā īstenotajām inovācijām. Visbeidzot, publikācijā ir aplūkots inovāciju pieņemšanas modelis un potenciāls uzsākt to pieņemšanas un pielāgošanas procesu Baltijas jūras reǵionā.

Atslēgvārdi: pārrobežu veselības aprūpe, bezpilota lidaparāts, inovāciju modelis, telemedicīna, telemedicīnas neatliekamās palīdzības ārsta pakalpojumi.

\section{Steffen Fleßa}

Veselības aprūpes vadības nodaḷa, Greifsvaldes Universitāte, Vācija /

Department of Health Care Management,

University of Greifswald, Germany 